Mastery of Nature 
This page intentionally left blank 


\section{Mastery of Nature}

Promises and Prospects

Edited by Svetozar Y. Minkov and Bernhardt L. Trout

\section{$\overline{\text { PENN }}$}

UNIVERSITY OF PENNSYLVANIA PRESS

PHILADELPHIA 
Copyright $\odot 2018$ University of Pennsylvania Press

All rights reserved. Except for brief quotations used for purposes of review or scholarly citation, none of this book may be reproduced in any form by any means without written permission from the publisher.

Published by

University of Pennsylvania Press

Philadelphia, Pennsylvania 19104-4112

www.upenn.edu/pennpress

Printed in the United States of America

on acid-free paper

$\begin{array}{llllllllll}10 & 9 & 8 & 7 & 6 & 5 & 4 & 3 & 2 & 1\end{array}$

A Cataloging-in-Publication record is available from the Library of Congress

ISBN: 978-0-8122-4993-4 
One wonders at those [things] which happen according to nature, insofar as one is ignorant of the cause, and at those [things] which happen contrary to nature, insofar as they come into being through art with regard to what is beneficial to human beings. For in many [cases], nature makes the opposite with regard to what is useful to us.

-Aristotle, The Mechanics

Nature's bequest gives nothing, but doth lend, And being frank she lends to those are free.

-Shakespeare, "Sonnet 4" 
This page intentionally left blank 